\title{
Amerigo Vespucci's Contribution to the Modernization of Cartographic Representation
}

\author{
Gyula Pápay $^{1}$
}

Received: 9 October 2020 / Accepted: 18 November 2020 / Published online: 17 December 2020

(c) The Author(s) 2020

\begin{abstract}
In 2019, the Rostock University Library acquired the report by Amerigo Vespucci (1454-1512) on transatlantic discoveries, which was published in 1505 by the city secretary Hermann Barckhusen (c 1460-1528/29) in Rostock under the title "Epistola Albericij. De novo mundo" [1505] and, unlike other editions, was published with a map. The special feature of the map is that it is the oldest map with a globular projection. Vespucci reported in a letter dated July 18, 1500 to Lorenzo di Pierfrancesco de' Medici about his voyage 1499-1500, which is an important source for the fact that his longitude determinations contributed to the realization that the transatlantic discoveries were about a continent. The letter also contains evidence that Vespucci was the originator of the globular projection. This marked the beginning of a departure from ancient traditions regarding the projections for world maps. To enable the combined representation of the "old world" together with the "new world" in one map, Vespucci's projection was later modified into an oval map, which was used, for example, by Franzesco Rosselli, Sebastian Münster and Abraham Ortelius.
\end{abstract}

Keywords History of map projections $\cdot$ Historical longitude $\cdot$ Measurement $\cdot$ Geographical discoveries

\section{Amerigo Vespuccis Beitrag zur Modernisierung der Kartographischen Darstellung}

Zusammenfassung Die Universitätsbibliothek Rostock erwarb 2019 den Bericht von Amerigo Vespucci (1454-1512) über die transatlantischen Entdeckungen, der vom dem Stadtsekretär Hermann Barckhusen (um 1460-1528/29) in Rostock 1505 unter dem Titel "Epistola Albericij. De novo mundo" [1505] im Gegensatz zu anderen Ausgaben mit einer Kartenbeilage gedruckt wurde. Die Besonderheit der Karte besteht darin, dass sie die älteste Karte mit Globularprojektion ist. Vespucci berichtete in einem Brief vom 18. Juli 1500 an Lorenzo di Pierfrancesco de' Medici über seine Reise 1499-1500. Dieser Brief ist zum einen eine wichtige Quelle dafür, dass seine Längengradbestimmungen zu der Erkenntnis beitrugen, dass es sich bei den transatlantischen Entdeckungen um einen Kontinent handelt. Der Brief enthält aber zum anderen auch den Nachweis, dass Vespucci der Urheber der Globularprojektion war. Damit begann eine Abkehr von antiken Traditionen bezüglich der Netzentwürfe für Weltkarten. Um die „neue Welt“ zusammen mit der “alten Welt” in einer Karte darstellen zu können, wurde der Netzentwurf Vespuccis später zu einer ovalen Karte modifiziert, die z. B. von Franzesco Rosselli, Sebastian Münster und Abraham Ortelius verwendet wurden.

Gyula Pápay

gyula.papay@uni-rostock.de

1 University of Rostock, Rostock, Germany

\section{Special Features of a Hemisphere Map Printed in Rostock in 1505}

In 2019 the Rostock University Library acquired the report of Amerigo Vespucci (1454-1512) on transatlantic discoveries, which was published in 1505 by the city secretary Hermann Barckhusen (ca. 1460-1528/29) in Rostockunder the title "Epistola Albericij. De novo mundo". Until then, only two copies of this print had been known to exist, located in Frankfurt and London. Vespucci's report, based 


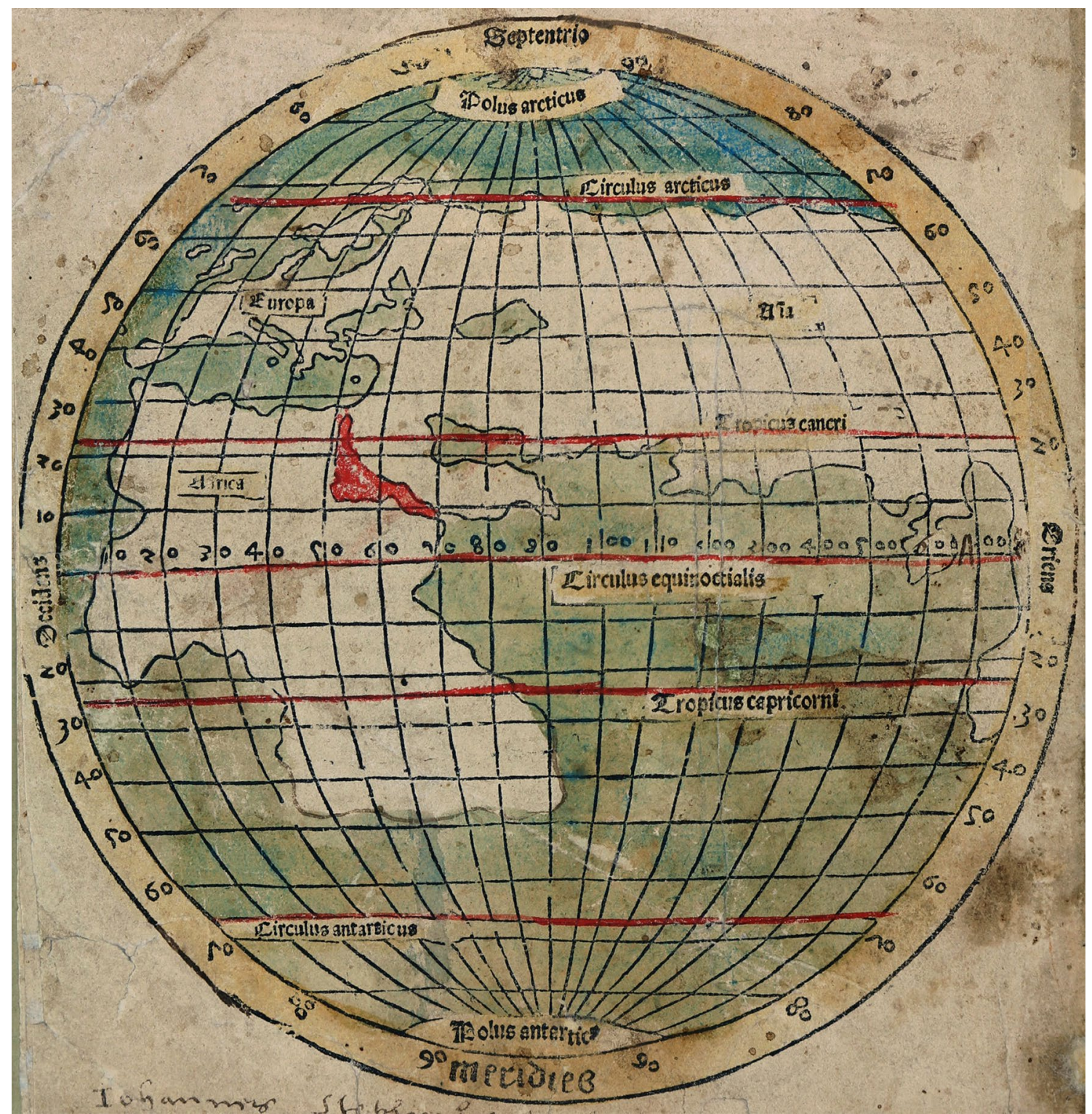

Fig. 1 Map from Amerigo Vespucci: "Epistola Albericij. De novo mundo" Rostock: Hermann Barckhusen 1505, University Library Rostock. The old world hemisphere presentation was erroneously intended to explain Vespucci's report on the new world. Vespucci's original map from 1500, which served as the basis for this map, had other functions. It illustrated the possible sea route from Lisbon to

on which Martin Waldseemüller referred to the new world as "America" in his world map published in 1507, experienced numerous editions. The special feature of the Rostockprint edition is that it is the only one to contain a map. ${ }^{1}$ It is an illuminated woodcut of a circular map (Fig. 1).

\footnotetext{
1 Thomas Horst (CIUHCT Lisbon) and employees of the Special Collection of the Rostock University Library were involved in the research.
}

India in globular projection. This projection also made it easier to measure distances. As the original is not preserved, the Rostock map is the earliest printed map in globular projection. It is also the only map whose authorship can be clearly attributed to Vespucci. The reception of Vespucci's map brought a breakthrough in the modernization of map projections

Strangely enough, only the "old world" was depicted in it and thus there is a blatant contradiction between the text and the map. This discrepancy led to the assumption that Vespucci could not be the author of the map. In search of the author of the map, a Nuremberg cartographer was first suspected. The most important indication for this hypothesis was a map printed in Nuremberg in 1506, for which the same cartographic basis was used as for the map printed in Rostock. The Nuremberg map is an uncolored woodcut in 


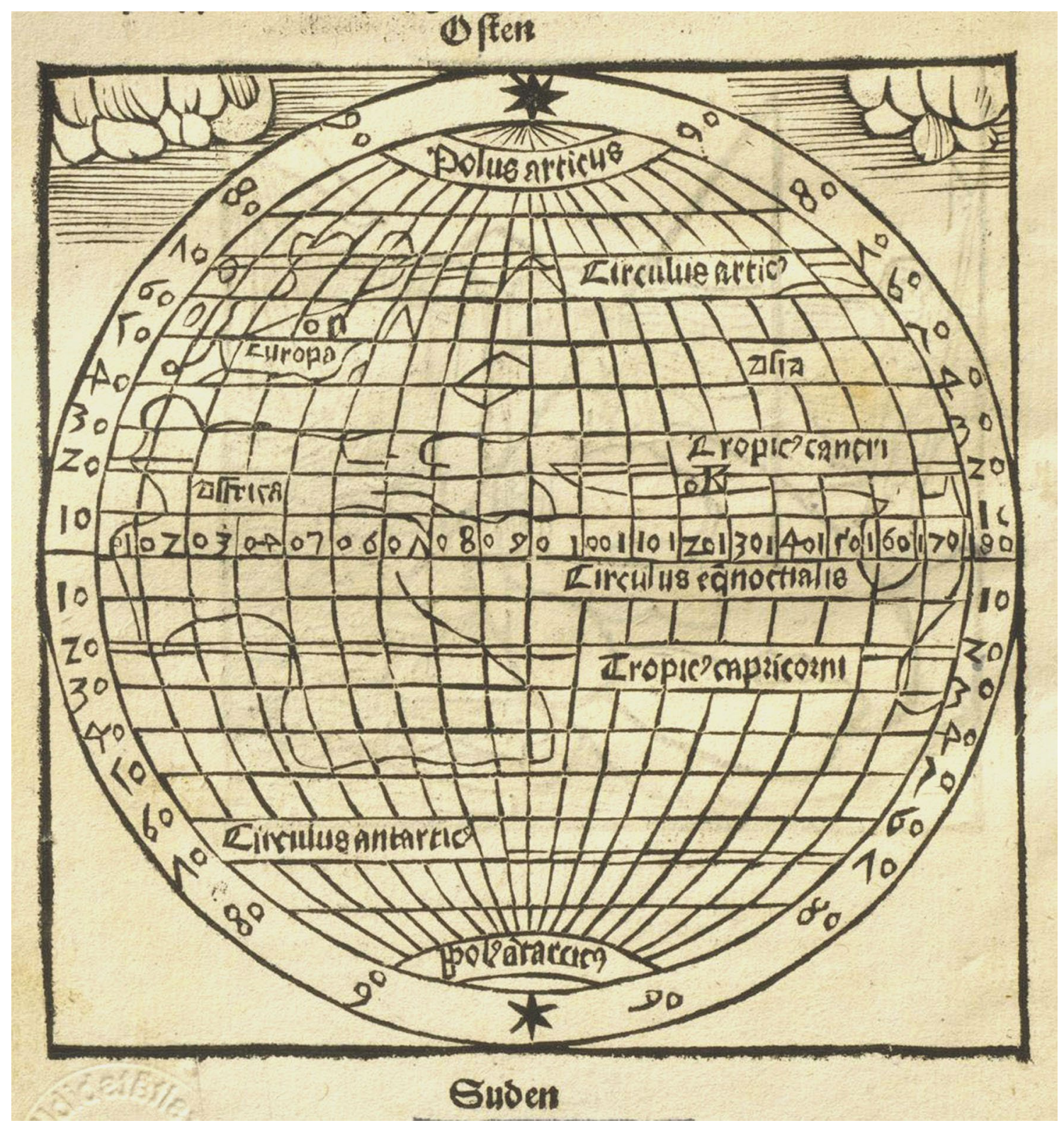

Fig. 2 Map from the „Den rechte[n] weg auszzu faren von Liszbona gen Kallakuth.“ [Nürnberg]: [Weissenburger], [1506], University Library Frankfurt am Main

which the structure of the original map is only fragmentarily reproduced (Fig. 2).

This map was printed in 1506 in Nurembergin two different leaflets. The texts of them are identical in content, only the spelling differs. This flyer experienced further editions, but the maps are always identical. For this reason, these maps are called "Nuremberg Map" here for simplicity. In contrast to the map of Rostock, it was not used to illustrate the Vespucci report, but to show the accessibility of Indiaby circumnavigating Africa. Both maps are provided with a commentary. In the Rostockmap, the commentary text is in Latin and contains an incomplete sentence at the end: "Habet nonnichil latentis energie precedens Albericii epistola. Quocirca, candide lector, haec subsequens tabula a Ptholomeo quidem mente paululum aliena, cum experientia autem recentiorum Cosmographorum et narratione superius praemissa facile quadrans, haud sine causa huius operis est subiecta. In qua non modo Europam et Asiam, verum etiam Affricam ipsam secundum eius continentem, quousque se in gradibus et longitudinalibus et latitudinalibus protendat, haud difficulter, absque tamen diversarum insularum annotatione propter tabule exiguitatem conspicere licet, ut non solum legere sed et coram quivis videre possit miranda et a mundi principio usque modo omnibus 
philosophis incomperta dei opificio..." "The preceding letter by Albericius contains some hidden potentiality. Therefore, dear Reader, the following table was added not without reason for this work: it differs somewhat to the ideas of Ptolemy, but will easily match with the experience of modern cosmographers and the preceding narration. Here you can easily find not only Europe and Asia, but also Africaitself, following its borders as far as much it expands in longitude and latitude, left apart only some marks to certain isles-due to the smallness of the table. So everybody can by himself not only read but also see the miracles, which were hidden to all philosophers from the beginning of the world until now,-by God's creation ..." The text was transcribed by Christiane Reitz and translated by Nikolaus Thurn.

There are differences in content between the Rostockand the Nurembergmap. The most remarkable difference is that the Nurembergmap shows Lisbonand Kallakuth/Calicut (Kozhikode), but not in the Rostockmap. Further differences can be interpreted as copy errors. In the Nurembergmap, the North Pole is labeled "East". ${ }^{2}$ In this map, again, the numbering of the meridians is correct throughout, but in the Rostockmap only up to $110^{\circ}$. The 120th longitude is numbered 200 and continued with 300 and so on. Strangely enough, the change in the way of counting takes place approximately in the length of Calicut. It is also possible that this is not only an error that occurred during copying, but also that there are distance indications in the original.

The cartographic projection is identical in both maps. It is the first known hemisphere representation in globular projection with a complete map grid. So far, the origin of the "globular projection" is dated very differently in the cartographic literature, e.g. its invention is attributed to Giovan Battista Nicolosi (1610-1670) (Schröder 1988, p. 140; Bollmann/Koch 2020). It is also widely believed that Peter Apian (1495-1552) was the inventor of this projection (Wagner 1949, p. 167 ff.). The extent to which the designs of Roger Bacon (1214-1294) and Pierre d'Ailly (1350-1420) could be regarded as precursors of globular projection is questionable because Bacon's design is only available as a reconstruction (Woodward 1990) and only the latitudes are shown in d'Ailly's map (Cambell 1987, fig. 24). In the map of Rostock and the map of Nuremberg, the equator and the middle meridian (90 degrees) are straight and true to length. The parallels are straight and evenly spaced. The meridians are also evenly spaced but elliptical. This projection differs considerably from the Ptolemaic projections used at that time and represents the prelude to a modern cartographic imaging system. In determining the author, several hypotheses were put forward, but could not be supported by sources. Extensive research finally led to the conclusion that

$\overline{2}$ Thomas Horst pointed out this mistake in 2006 (Horst 2006, S. 19).
Vespucci, who initially did not come into question, was the author of this projection.

\section{Vespucci's Report on His Second Voyage (1499-1500)}

Amerigo Vespucci was born in Florence in 1454. Already in his youth, he acquired special knowledge in geography and astronomy. His uncle Giorgino Antonio Vespucci (ca. 1434-1514) played an important mediating role (Van Duzer 2018, p. 74 ff.). Later on, he educated himself autodidactically in navigation. After a two-year stay in Paris, he received a position in the bank of Lorenzo di Pierfrancesco de' Medici (1463-1503) in 1482. As from 1491, he continued his work for this bank in Seville. Since this bank branch was involved in equipping the ships for exploration, he came into contact with Christopher Columbus (1451-1506). In 1497 he was allowed to take part in a transatlantic voyage. He reported about this expedition, which lasted from May 1499 to June 1500 , to Lorenzo di Pierfrancesco de' Medici in a letter dated July 18,1500 . According to his report, he determined longitudes during the voyage. He carried out the astronomical determination with the help of the ephemerides of "Giovanni Monteregio", i.e. by Johannes Regiomontanus (1436-1476) and the "Table of King Alfonso", i.e. the "Alphonsine Tables", which were created in Seville in the thirteenth century (Bandini 1745, p. 71 f.; Bandini 1748, p. 239 f.). The basis for astronomical positioning was the conjunction of the Moon and Mars. Correct results could not yet be obtained in this way at the time (Humboldt 1836, p. $512 \mathrm{f}$.), but the entry of these inaccurate values into a world map would already have to lead to the realization that Asia is very far away from the newly discovered regions. Regarding the length of the earth's circumference, Vespucci did not directly correct Ptolemy's data. Like Ptolemy, he also assumed 180,000 stadiums, but in the conversion of the stadiums into leguas he proceeded differently than, for example, Toscanelli (1397-1482), in whose conversion the circumference of the earth was only about $30,000 \mathrm{~km}$. Vespucci specified the earth's circumference as 6000 leguas, which resulted in $162 / 3$ leguas for a meridian degree or an equatorial degree. In his opinion, this information was consistent with the value he had obtained by measuring distances at sea. When converting to meters, one could assume a minimum value of $5,555.555 \mathrm{~m}$ (corresponds to a Tuscan legua), the maximum value could be $6 \mathrm{~km}$ (Wallisch 2012, p. 179). The circumference of the earth, on which Vespucci's calculations were based on, was between $33,330 \mathrm{~km}$ and $36,000 \mathrm{~km}$ in length. This was, therefore, larger than the circumference of the earth assumed by Toscanelli and Christopher Columbus (1451-1506). Vespucci's longitude determinations and the discovery of the very long extension of the 
east coast to the south provided the basis for the realization that the areas discovered by Columbus did not belong to Asia. It is probably for this reason that Vespucci considered his greatest achievement to be his longitude determinations. In 1501 he wrote that this task would have cost him ten years of his life, as it cost him a lot of sleep. He hoped to be famous for his results for many years to come: "Per causa della detta longitudine io ho perduti molti sonni, e ho abreviato la vita mia dieci anni, e tutto tengo per bene speso, perché, spero venire in fama lungo secolo, se io torno con salute di questo viaggio." (Letter from Cabo Verde, June 4, 1501, quoted from Levillier 1951, p. 128).

In 1500, Vespucci described the newly discovered continent as "terra ferm", i.e. mainland (Bandini 1745, p. $761 \mathrm{f}$.; Bandini 1748, p. 245 f.). Not until he reported on his third voyage in 1502 did he use the term "Mondo nuovo" ("New World") instead of "terra ferma". Vespucci could not know how far this continent extended in a westerly direction. The Pacific Ocean was not seen by a European until 1513 after Vespucci's death. Vespucci suspected a land connection to Asia based only on the observation of the local fauna. ${ }^{3}$

In a letter to Lorenzo di Pierfrancesco de' Medici dated July 18, 1500, Vespucci noted that he and the Florentine Francesco Lotti had sent the letter and two representations of the world to Florence, which he had worked out with his own hand and knowledge (or skill): "due figure della descrizione del mondo fatte, e ordinate di mia propria mano, e savere" (quoted from Bandini 1745, p. 85). He described the first map as "figura piana", the second as "Apamundo in corpo sperico", i.e. "mappamondo in corpo spherico", i.e. a map of the world in round shape. According to the previous interpretations, this was a "flat" map and a globe (Van Duzer 2018, p. 73; Heijkant 2003, p. 294). The "figura piana" was most likely a square map, i.e. a map with a so-called "plate carree projection". This type of map, whose knowledge dates back to antiquity (Strabo: Geographika, 2.5.16.), is based on a cylindrical projection. It was already used by Marinus of Tyre around $100 \mathrm{AD}$. The projection consists of straight parallel meridians and likewise straight parallels of latitude. Apparently, Toscanelli's map of 1474 (Wagner 1894), as well as the map of Juan de la Cosa (1500) and the so-called "Cantino map" (1502), had this projection. Vespucci did not add an explanation to the "figura piana" in the letter. The explanation was likely entered directly into the map as a comment. Another reason for this could be that Vespucci presented the results of his longitude and latitude determinations in this map, which he achieved during the voyage, as reported in detail elsewhere in the letter. Concerning the

\footnotetext{
${ }^{3}$ In contrast to Martin Lehmann, Vespucci's statement in this regard cannot be interpreted to mean that he considered this continent to be an extension of the Asian continent (Lehmann 2013).
}

circular map, he reported that he had already received great appreciation for it from their sovereigns and had received an invitation from the King of Portugal. In the original text, the sovereigns are designated with "Re" (Bandini 1745, p. 85). Since "Re" and not "Regina" was used here, from this one can deduce that the Portuguese king was meant by this. In Castile, the queen Isabella, who was to be titled "Regina", reigned. Possibly the Portuguese king's interest in Vespucci was motivated less by this map than by the "figura piana". About the same time as this map, the Portuguese king received the report of Pedro Álvares Cabral (ca. 1468-1520) about the Brazilian coast, which he reached in April 1500 with 13 ships. Cabral sent a ship with his report back to Lisbon, which returned to Europe at about the same time as Vespucci. It is possible that on the return of both ships there was an encounter. In any case, Vespucci already knew in July 1500 that Cabral was sailing on to India with 12 ships. Both reports could find their way into the secret map whose copy was smuggled to Italy by Alberto Cantino. This copy was made in 1502 and is called the "Cantino Planisphere".

While the "figura piana" contained new elements in terms of content, the circular map, according to a note by Vespucci, did not offer much new in terms of content, but its map projection structure was innovative. Consequently, Vespucci proudly presents his new creation. However, he feared that his innovation might be viewed critically in Florence, where several people possessed knowledge about "the shape of the earth" ("la figura del mondo"). What is meant by this is quite obviously the capture of the globe by map projection. These experts are warned by him: "However, whoever wants to improve me, wait until I come myself; for it may be that I will defend myself" (Bandini 1748, p. 256). From the contents of the letter, it is also clear that the attached map, with which he presented his innovation, did not depict the "new world". It showed how to get from Lisbon to Calicut by sea. It was thus limited to the eastern hemisphere. Vespucci did not attach great importance to the Portuguese voyages of discovery, since on their expeditions to India they traveled to areas that were already known to the cosmographers. From these remarks, it also emerges that Vespucci did not see the significance of his circular map in its contents, but in the new type of projection. This also explains why the contours of the continents are not executed with the care one would expect from a good cartographer. The representation of the geographical structure could mainly only be based on a Ptolemaic world map. It can be assumed that this was an edition from 1478 since the Vespuccis had owned were in possession of this edition (González Germain 2018). Based on some peculiarities regarding the representation of the coastlines in the Rostock map, such as the pointed shape of the northern coast of the Sea of Azov, it can be concluded that the world map was published in Rome in 1478. 
Vespucci's primary intention was the explicit cartographic representation of the spherical shape of the earth, which was only hinted at in the Ptolemaic maps. His second principle was to represent the spherical shape in such a way as to facilitate the measurability of distances.

These principles excluded the use of perspective projection. The third projection of Ptolemy was a projection in which the spherical shape of the earth could be reproduced pictorially. However, it was not used in the so-called "Ptolemaic maps". Its earliest known use was in the Stabius-Dürer map of 1515, but Vespucci did not use it because of the perspective distortion of the distances. His suggestion to present the world in a cartographic structure different from that of Ptolemy was a courageous act which Vespucci was aware of; otherwise, he would probably not have feared the hostility that innovations often entail. Evidence of reflection on one's achievements is an extremely rare case in the history of cartography. This is another reason why Vespucci's letter from 1500 is a remarkable document.

\section{Transmission of the Circular Map of Vespucci}

The reception of the circular map was twofold. In Florence, the interest was primarily directed at the map content and not at the novel projection. The sensation that new trade connections were possible led to the publication of Vespucci's map in leaflets that also reached more northern parts of Europe, such as Nuremberg. Due to the close economic ties between the southern German region and the major Italian cities, there was also a lively map transfer, with Franzesco Rosselli (1445-before 1513) developing an outstanding activity. The historian Marino Sanuto (1466-1536) honored him with an epigram (1530) as an important cosmographer who depicted the earth in a circle and combined the findings of Ptolemy with those of the Iberian explorers (Carlton 2015, p. 52). Probably this did not mean a circular but an oval world map, which Rosselli published in 1508. Another source reports that Rosselli probably also printed a circular map. In 1528 a citizen of Florence bought a "la spera pichola" from the Rosselli store. The low price suggests that it was not a globe but a small circular map (Carlton 2015, p. 70). The most convincing proof that Rosselli knew Vespucci's map is the map grid of the oval map, in which Vespucci's projection was extended to both hemispheres. According to current knowledge, there is no known copy of Vespucci's map, which was probably published in Italy as a single-sheet print or as a leaflet. However, Vespucci's map printed in them was not lost, since it was reprinted as copies in Rostock in 1505 and Nuremberg in 1506. Since Vespucci's reports reached German regions with delay, reports that were not published at the same time were considered simultaneous. Barckhusen may have acquired the Italian source map in Nuremberg or received it from the Rostock professor Egbertus Harlem (before 1500-1539), who worked in Rostock around 1505 and had a large collection of leaflets. This collection is also said to have included those that could be associated with Vespucci (Sarnow/Trübenbach 1903, p. 10). The map of Vespucci, which was created before the third voyage (1500) and his report on that voyage (1502) were possibly received by Barckhusen at the same time. In addition, he could not yet have known a map depicting the "new world". This led to the incorrect interpretation of the map in Rostock. The map printed in Rostock was attached to Vespucci's report on his third journey, although the map had already been produced in 1500 and had no connection to the report in terms of content. The occurrence of such a discrepancy can only be explained by the fact that Vespucci's name was mentioned in the source map. This misinterpretation also had a positive effect, as it contributed to the structural preservation of the original map. To a lesser extent, the map printed in Nuremberg also contributed to this.

With the knowledge of the history of the origin and transmission of this map, the incomplete map commentary can be finalized. Vespucci distinguishes in his letters between cosmographers and philosophers. The cosmographers pursue the task of describing the world geographically or cartographically, whereas the explanation of the world is the responsibility of the philosophers. The ignorance of philosophers mentioned in the comments on the maps printed in Rostock and Nuremberg had no cosmographic reference. Vespucci mentioned several times in his letters that the habitability of the southern hemisphere was unknown to all philosophers. This annotation also seems to be a hint that in his map the southern and the northern part of the hemisphere are treated equally cartographic, in contrast to the Ptolemaic projections, optimized for the representation of oecumene, that is, the inhabited world.

The leaflet printed in Nuremberg describes the "correct" sea route from Lisbon to Calicut. There are clear indications of Vespucci. In the map commentary, the original designation of the map "sphere" was taken over as "Sperre". In the report of his third voyage, Vespucci created a representation of antipodes (Wallisch 2012, p. 37). This triangle symbol on the title page of the pamphlet is also a reference to Vespucci (Horst 2006, p. 18). The text passage under the title is most likely taken from Vespucci's report on the second journey. It contains the information that the Portuguese king sent several ships to Calicut to explore and "conquer" the area (Levillier 1951, p. 122). The route leading there is indicated in the map by the localization of Lisbon and Calicut, which was presumably taken from the original map.

The partially very schematic adoption of the coastline as well as the error that north was marked "east" is an indication that the copier could hardly have been able to locate 
Calicut. It is quite possible that the map in the leaflet printed in Italy, which served as a base map for the Nuremberg leaflet, contained a route description by Vespucci. At the beginning of his third trip, Vespucci met returning ships from Calicut, about which he reported to Florence in a letter from Cabo Verde on June 4, 1501 (Levillier 1951, pp. 146-153).

The map printed in Rostock contains an inconspicuous reference to the time of origin of the original map. In the woodcut, the south coast of Africa was left open, since the author of the original map already knows about Vasco da Gama's voyage to India, completed in 1499 , but did not yet have precise information about the course of the south coast of Africa. When coloring the map, the open area on the coast was closed schematically by drawing. This is where the difference between the Rostock and the Frankfurt copy arose. Another remarkable feature of the maps printed in Rostock and Nuremberg is the shortened representation of the extending Mediterranean area. It represents a very early, previously unknown correction of the Ptolemaic maps, in which the Mediterranean appears much too long due to a miscalculation by Ptolemy. Only decades later, attempts were made to correct this misconception. Gerhard Mercator (1512-1594) played an important role in this. It is quite conceivable that Vespucci made such a reduction in conjunction with his determination of longitudes since Ferrara was mentioned several times as the reference meridian. ${ }^{4}$

\section{Construction of the Cartographic Projection Vespucci's}

Figure 3 shows the possibility to convert a square map with equirectangular projection (step 1) into a globular projection. A circle with a diameter of two earth radii is inserted into this degree grid (step 2). The parallels are shortened according to the circle shape (step 3). The shortened meridians are divided equally, in this case into 18 parts. The meridians are curved according to the division (step 4). It can be assumed that Vespucci proceeded in this way. The creation of this projection was much easier than the Ptolemaic projections. This projection entailed the advantage of visualizing the shape of the earth and better possibilities for determining distances at the same time. The illustration shows that his imaging method was simple but ingenious. While Ptolemy combined fidelity of distance with faithful reproduction of

\footnotetext{
4 A fragmentary letter by Vespucci from 1502 seems to contradict this view, as the difference in longitude between the meridians of Lisbon and Ferrara is far too great (Levillier 1951, p. 294.). However, this is obviously an incorrect rendering of the original indication, since the distance between Lisbon and Ferrara exceeds even the Ptolemaic value. In the Rostock map, this distance is about 5 degrees shorter than in the Ptolemaic map of 1478.
}

the continents, for Vespucci the even distances in the map were more important than the approximate fidelity of the geographical structure. It was limited to the circular representation of the hemisphere. Vespucci's projection is a modern projection, as it belongs to the not true perspective projections.

\section{Reception of Vespucci's Map Projection}

There are no known sources for how Florence reacted to Vespucci's innovative representation. The effect can only be determined indirectly. Maps published after 1500 show that a rethinking process was underway by increasingly turning away from ancient traditions. The publication of Vespucci's map may also have played a certain role in this process. The geographical discoveries certainly provided greater motivation for this. Polar hemisphere maps appeared which were more suitable for the presentation of the discoveries. Rosselli published such a map in 1506 , which was produced by Giovanni Contarini (?-1507). It was the first printed map in which the "new world" was represented. Giovanni (Juan) Vespucci (1486-?) designed a world map with two hemispheres in 1524. He was a nephew of Amerigo Vespucci, who inherited maps and navigation devices from his uncle (Van Duzer 2018, pp. 79-83). In his world map, the northern hemisphere appears as a circle, while the southern hemisphere appears as two separate semicircles. The projection of the northern hemisphere is an inversion of his uncle's hemisphere map: the transversal position was transformed into the polar projection. The parallels of latitude appear as circles and the meridians as straight lines. The division into degrees was carried out in equidistant spacing. Nevertheless, one can only cautiously assume that Giovanni would have derived his projection from his uncle's because the globular projection in the polar position was probably used much earlier in astronomy.

In terms of the reaction to his cartographic innovation, Vespucci proved to be a clairvoyant only to a limited extent. His globular projection was modified, but not improved; it was only spatially expanded to be able to represent the "new world". This is how the world map printed by Rosselli in 1508 came about, which was long considered as the modern cartographic representation of the world. They were used by several well-known cartographers, e.g. by Benedetto Bordone (1460-1531) (Fig. 4), Jacopo Gastaldi (c. 1500-1566), Sebastian Münster (1488-1552) and Abraham Ortelius (1527-1598). Even the earliest complete world map printed in China appeared in the modified "Vespucci projection". It was produced by Matteo Ricci (1552-1610) with Chinese help in 1584. (Elman 2005, p. 127) The first map in which the "new world" was named America had an ancient projection, which Waldseemüller merely expanded 

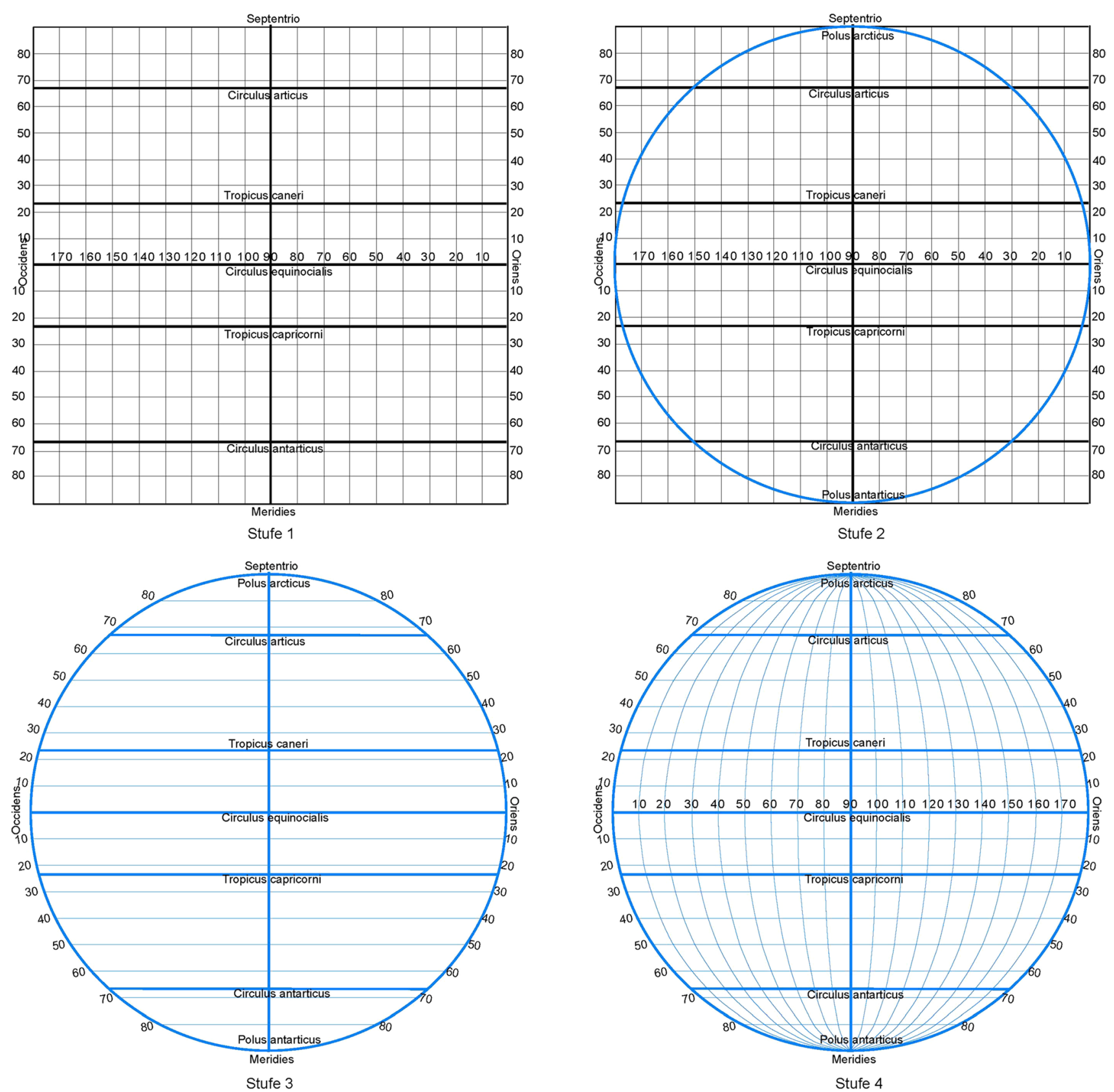

Fig. 3 From square map (equirectangular projection) to globular projection: construction of Vespucci's projection

spatially in 1507 . Two secondary maps were assigned to this world map. The small map of the "old world" is assigned to Ptolemy with a portrait, while the map of the "new world" is attributed to Vespucci. An irony of fate: the map of America appears in the Ptolemaic projection.

Vespucci's globular projection was mainly used in modified versions, but knowledge of the original form has not been lost either. Franciscus Monachus (c. 1490-1565) published two small circular hemisphere maps in 1526 that illustrated the Spanish and Portuguese territories. In 1527 (Monachus 1527) Henricus Loriti Glareanus (1488-1563)
(Glareanus 1527) published this projection as a structural sketch in his "De geographia liber unus". ${ }^{5}$ Bordone created an oval world map in 1529, but he also published a structural sketch of the circular map. (Fig. 5) Battista Agnese (c. 1500-1564) also drew not only an oval world map (1544)

\footnotetext{
${ }^{5}$ According to Thomas Horst, this work was often bound together with Apian's "Cosmographicus Liber" (1524) and thus this illustration was attributed incorrectly to Apian.
} 


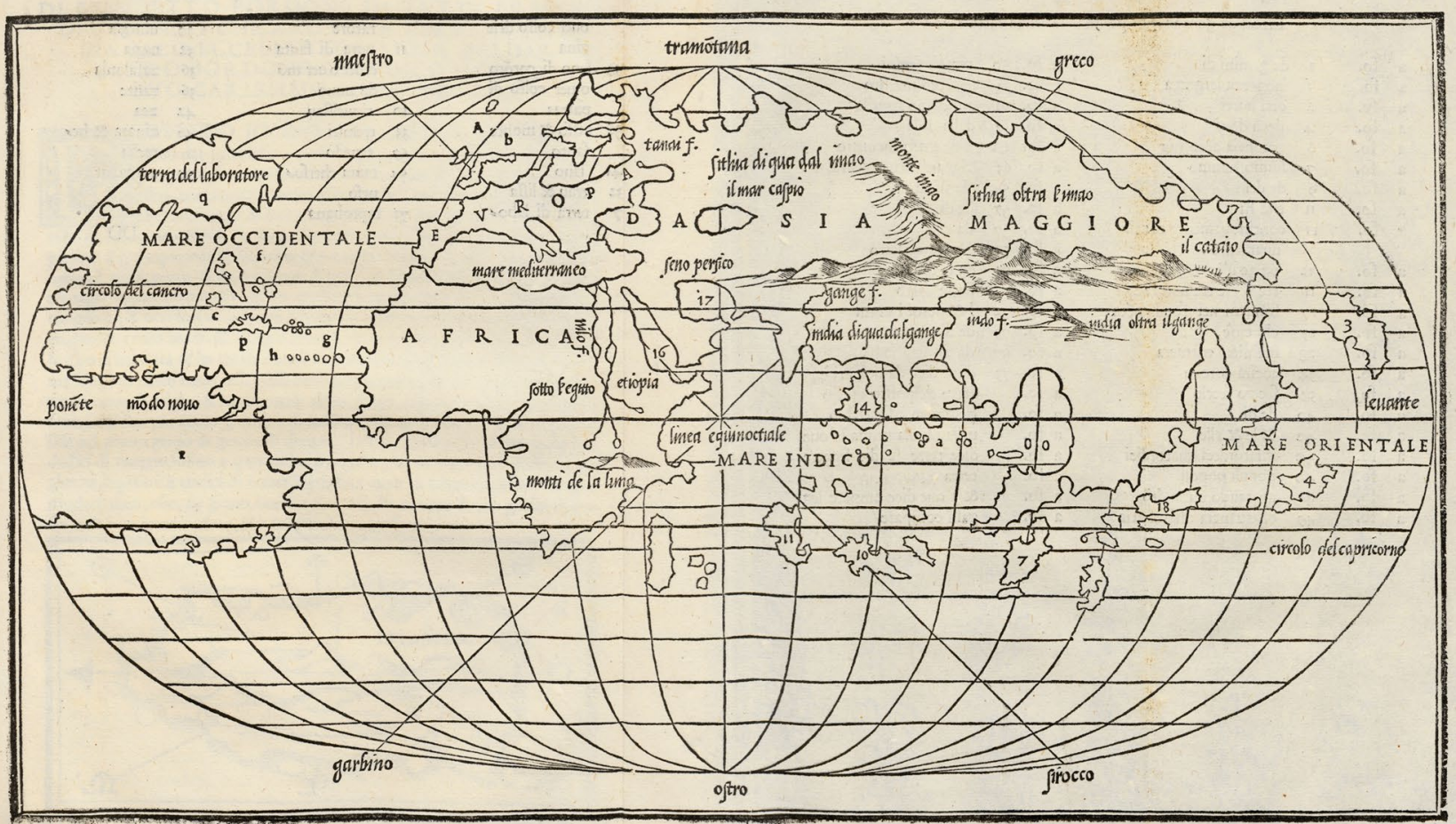

Quefte linee che fono $\mathrm{Fer}$ il longo di quefto uniuerfale da gli fapienti furono appellate lie nee parallele, \& quelle che tengono forma curua in modo di arco, fono nominate meridia

Fig. 4 World map by Benedetto Bordone 1528 in Vespuccis modified globular projection. (University Library Rostock)

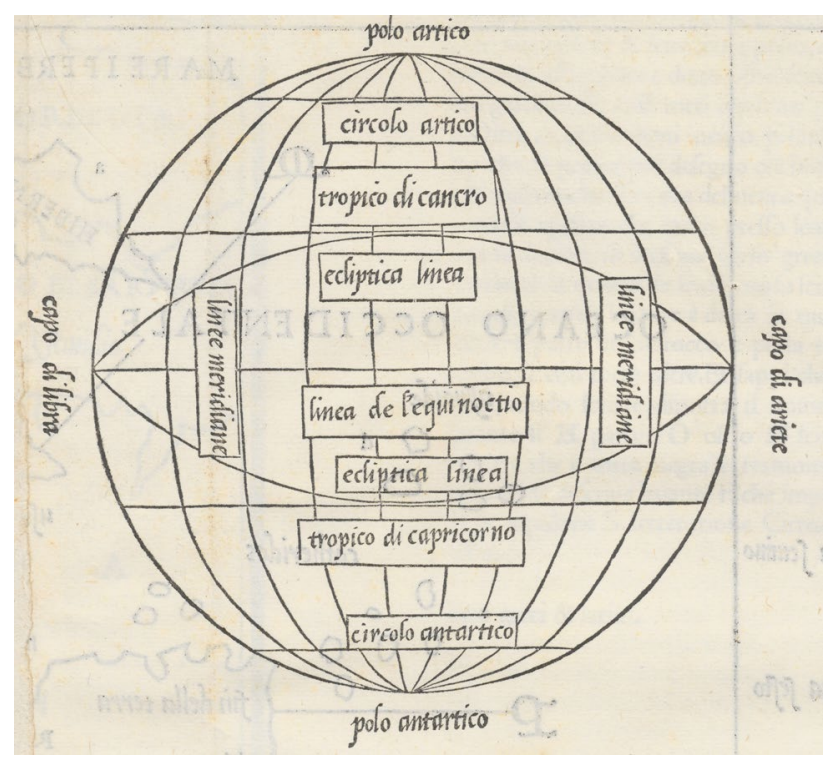

Fig. 5 Structural sketch of Vespuccis modified globular projection. Benedetto Bordone 1528. (University Library Rostock)

but also a circular map with the same projection (cf. inter alia Baumgärtner 2015, p. 29).
The world map by Giuseppe Rosaccio (c. 1552—c. 1627) occupies a special place in Vespucci's reception. The world map printed around 1610 consists of two hemispheres with Vespucci's projection. It has the effect of a reminiscence. This modern map is juxtaposed with the outdated antique representation of the world with Ptolemaic projection. The secondary representations also contain allusions to Vespucci, without mentioning his name. In a miniature image, the parallels of latitude appear as parallel straight lines with the inscription "PARALELE". In a second image, only the meridians are present with the inscription "MERIDIANI". (Fig. 6) These miniature images seem to indicate the construction of the modern projection. The dedication of the map is also remarkable, as it is addressed to a member of the Medici family, to Cosimo II de' Medici (1590-1621). He was Grand Duke of Tuscany and a promoter of science. From him, Galileo Galilei (1564-1641) received good research opportunities and he also defended Galilei during the Inquisition. Without reference to Vespucci this map was described by D. Woodward (2007, p. 4). 


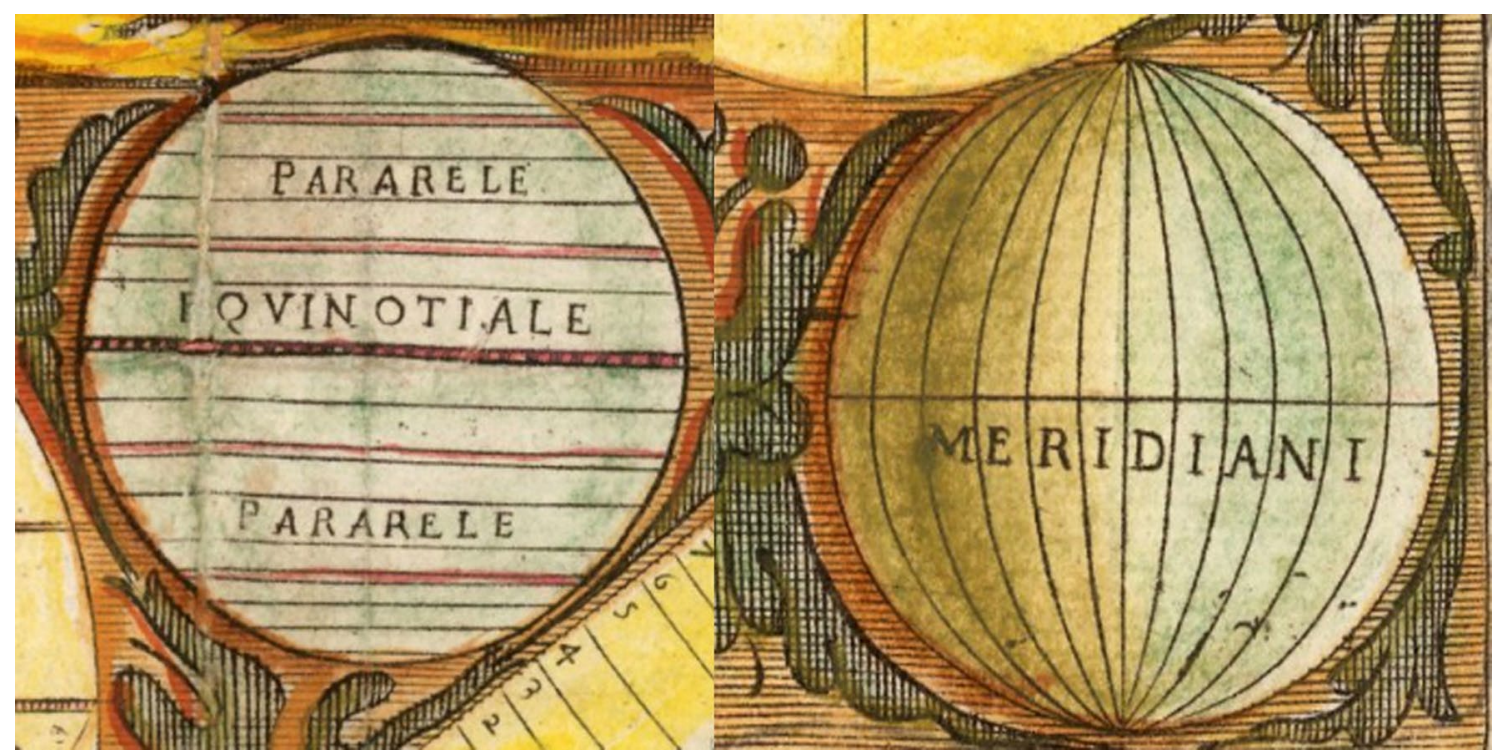

Fig. 6 Supplementary illustrations in the world map by Giuseppe Rosaccio 1610. (University Library Rostock)

\section{Concluding Remarks}

In this article, the origin of the map, which was printed in Rostock in 1505, could be largely clarified. An explanation could also be given for the contradictions regarding its context. Amerigo Vespucci's innovative projection represents a turning point in the history of cartography. It contributed significantly to overcoming the Ptolemaic tradition. It marked the beginning of a development that also led to a more adequate integration of the continent he named into the world map. The honor Vespucci received by naming America was exaggerated. However, he did not receive the credit for the modernization of the cartographic representation which would have been completely justified.

With the expeditions began the colonization as a dark chapter of world history. However, Vespucci's expeditions were not motivated by financial enrichment. In a letter dated June 4,1501 , he wrote that his voyages were not intended to acquire trade goods but to discover new territory (Heijkant 2003, p. 304). In the same year as Vespucci's report was printed in Rostock, he turned to Columbus with the request to get him a job to improve his financial situation. ${ }^{6}$ In his letter of 1500 , he castigated the "extraordinary penuriousness" that was associated with overseas voyages.

The expeditions of discovery were then and long afterwards reflected from a European-centric perspective. Both

\footnotetext{
${ }^{6}$ Letter from Columbus to his son dated February 5, 1505. Original in the collection of the Duke of Veragua. English translation: https ://archive.org/stream/authenticletters00colu/authenticletters00colu_ djvu.txt
}

the term "new world" and its designation "America" were shaped by this view. However, the globular projection designed by Vespucci was by no means Europe-centric. In Vespucci's map with the globular projection, Europe appeared on the periphery of the eastern hemisphere.

Open Access This article is licensed under a Creative Commons Attribution 4.0 International License, which permits use, sharing, adaptation, distribution and reproduction in any medium or format, as long as you give appropriate credit to the original author(s) and the source, provide a link to the Creative Commons licence, and indicate if changes were made. The images or other third party material in this article are included in the article's Creative Commons licence, unless indicated otherwise in a credit line to the material. If material is not included in the article's Creative Commons licence and your intended use is not permitted by statutory regulation or exceeds the permitted use, you will need to obtain permission directly from the copyright holder. To view a copy of this licence, visit http://creativecommons.org/licenses/by/4.0/.

\section{References}

Bandini AM (1745) Vita et lettere di Amerigo Vespucci gentiluomo fiorentino, raccolte e illustrate dall'abate Maria Bandini. Nabu Press, Firenze

Bandini AM (1748) Americus Vespucci, eines florenzischen Edelmannes, Leben und nachgelassene Briefe...Hamburg: Georg Chriftian Grund. Adam Heinrich Holle, Leipzig

Baumgärtner I (2015) Die Portolan-Atlanten des Battista Agnese. In: Bischoff M, Lüpkes V, Crom W (eds) Kartographie der frühen Neuzeit. Weltbilder und Wirkungen. Jonas-Verlag, Marburg, pp 19-36

Bollmann J, Koch W G (eds) (2020) Lexikon der Kartographie und Geomatik. https://www.spektrum.de/lexikon/kartographie-geoma tik/

Campbell T (1987) The earliest printed maps 1472-1502. The British Library, London 
Carlton G (2015) Wordly consumers. The demand for maps in renaissance Italy. University of Chicago Press, London

Cattaneo A (ed) (2018) Shores of Vespucci. a historical research of Amerigo Vespucci's life and contexts. Peter Lang, Berlin

Den rechte[n] weg ausz zu faren von Lißbona gen Kallakuth. vo[n] meyl zu meyl. Auch wie der kunig von Portigal yetz newlich vil galeen vn[d] naben wider zu ersuchen vnd bezwingen newe land vnnd insellen durch kallakuth in Jndien zu faren. Durch sein haubtman also bestelt als hernach getruckt stet gar von seltzsamen dingen [1506], [Nürnberg: Johann Weißenburger]. Holzschnitt: Georg Stuchs Nürnberg.

Elman BA (2005) On their own terms. Harvard University Press, Cambridge

Epistola Albericij (1505) De novo mundo. Hermann Barckhusen, Rostock

Glareanus HL (1527) De geographia liber unus. Johannes Faber, Basel

González Germain G (2018) The copy of Ptolemy's Geography (Rome, 1478) owned by the Vespuccis. In: Cattaneo A (ed) Shores of Vespucci, pp. 87-99.

Heijkant MJ (2003) Die Darstellung des Reiseberichtes in den Briefen von Amerigo Vespucci an Lorenzo di Pierfrancesco de Medici. In: Ertzdorff X, Giesemann G, Schulz R (eds) Erkundung und Beschreibung der Welt. Rodopi, Amsterdam, pp 289-309

Herkenhoff M (1996) Die Darstellung außereuropäischer Welten in Drucken deutscher Offizinen des 15. Jahrhunderts. Akademie Verlag, Berlin

Horst T (2006) „Am Anfang war das Gewürz“ Vor 500 Jahren kehrte der Allgäuer Balthasar Sprenger von einer Indienfahrt zurück. Er hinterließ einen eindrucksvollen Reisebericht. Literatur in Bayern 85. Allitera Verlag, München, pp 13-21

Humboldt A (1836) Kritische Untersuchungen über die historische Entwicklung der geographischen Kenntnisse von der Neuen Welt und die Fortschritte der nautischen Astronomie in den 15ten und 16ten Jahrhundert. Nicolai'sche Buchhandlung, Berlin

Lehmann M (2013) Amerigo vespucci and his alleged awareness of America as a separate land mass. Imago Mundi 65(1):15-24
Levillier R (1951) El Nuevo Mundo. Cartas relativas a sus viajes y descubrimientos. Textos en italiano, español e inglés. Editorial Nova, Buenos Aires

Monachus F (1527) Hoc orbis hemisphaerium cedit regi Lusitaniae. Hoc orbis hemisphaerium cedit regi Hispaniae, Antwerpen

Sarnow E, Trübenbach K (1903) Mundus Novus Ein Bericht Amerigo Vespucci's an Lorenzo de Medici über seine Reise nach Brasilien in den Jahren 1501/02 nach einem Exemplare der zu Rostock von Hermann Barckhusen gedruckten Folioausgabe, im Besitze der Stadtbibliothek zu Frankfurt a. M. Faksimile und mit Einleitungen. Heitz und Mündel, Straßburg

Schröder E (1988) Kartenentwürfe der Erde. Kartographische Abbildungsverfahren aus mathematischer und historischer Sicht. Teubner, Leipzig

Van Duzer Ch (2018) New insight on the maps of the Vespuccis: Giorrgio Antonio, Amerigo and Giovanni. In: Cattaneo A (eds) Shores of Vespucci. A historical research of Amerigo Vespucci`s life and contexts. Berlin: Peter Lang, pp. 73-85

Wagner H (1894) Die Rekonstruktion der Toscanelli-Karte von Jahre 1474. In: Nachrichten der K (ed) Ges. der Wissenschaft zu Göttingen, issue 3, pp. 208-312.

Wagner K (1949) Kartographische Netzentwürfe. Bibliographisches Institut, Leipzig

Wallisch R (2012) Der Mundus Novus des Amerigo Vespucci. Verlag der Österreichischen Akademie der Wissenschaften, Wien

Woodward D (1990) Roger Bacon's terrestrial coordinate system. Ann Assoc Am Geogr 801:109-122

Woodward D (2007) Cartography and the Renaissance: Continuity and Change. In: Woodward D (ed) The history of cartography, cartography in the European Renaissance. The University of Chicago, Chicago 